\title{
EFFECTS OF DIFFERENT MOLE SPACINGS ON THE YIELD OF SUMMER GROUNDNUT
}

\author{
O. L. Kolekar ${ }^{1}$, S. B. Patil ${ }^{2}$, S.D. Rathod ${ }^{3}$ \\ ${ }^{I}$ P.G. Student, Department of Farm Machinery and Power, College of Agril Engg \& Tech., Parbhani \\ ${ }^{2}$ Professor, Department of Farm Machinery and Power, College of Agril Engg \& Tech., Talsande \\ ${ }^{3}$ Assistant Prof, National Agricultural Research Centre, Kasabe Digraj, Dist.-Sagali
}

\begin{abstract}
The research work carried out earlier has shown the effective installation of mole drains at various depths. The effect of mole drainage system on the crop parameters are studied on soybean. The mole plough manufactured last year studied and evaluated for its performance at various depths. The effect of the mole plough developed needs to be studied from the crop point of view so the present study undertaken to study the effect of mole drains spacing on summer groundnut yield.

A tractor $65 \mathrm{HP}$ was selected to make drains of $2 \mathrm{~m}, 4 \mathrm{~m}$ and $6 \mathrm{~m}$. The effect of mole drain spacing at $2 \mathrm{~m}, 4 \mathrm{~m}$ and $6 \mathrm{~m}$ plot without drain i.e. control were studied by standard procedure and following conclusions were made. The plant height, No. branches per plant, No. of pods per plant, weight of pods per plant was highest in $4 \mathrm{~m}$ drain spacing followed by $6 \mathrm{~m}, 2 \mathrm{~m}$ and control plot. The total yield of groundnut was highest in $4 \mathrm{~m}$ mole spacing followed by $6 \mathrm{~m}, 2 \mathrm{~m}$ and control and the total yield in $4 \mathrm{~m}$ drain was $69.20 \%$ more than the control.
\end{abstract}

\section{INTRODUCTION}

National commission on Agriculture Govt. of India (NCA. 1976) defined an area as waterlogged when the water table causes saturation of crop roof soil resulting to restriction to air circulation, decline in oxygen and increase in $\mathrm{CO}_{2}$ levels.

The physical effects of water logging are lack of aeration in the crop root zone, difficulty in soil workability and deterioration of soil structure. Its chemical effect is soil salination.

\subsection{Present Status of Drainage}

The effects of water logging were observed in the Western Yamuna Canal zone around 1850 AD. In the Deccan plateau, where the Neera irrigation project was commissioned in 1984, water logging started with a few years of starting irrigation.

In many coastal areas excessive groundwater exploitation has caused seawater intrusion, worsening the salinity problem. There are extensive low lying areas in the rice growing coastal belts of eastern and south eastern region of India where poor drainage seriously affects crop production in the Manson season.

\section{DIFFERENT TYPES OF DRAINAGE SYSTEM AND THEIR COST ECONOMICS}

The methods can be adopted for reclaiming waterlogged and salt affected areas are surface drainage, subsurface drainage, vertical and biological drainage.

Structural measures are summarized as surface, sub surface (ground water or tile drainage and mole drainage.

\subsection{Surface Drainage}

Surface drainage can be described as (ASAE, 1979) "the removal of excess water from the soil surface in time to prevent damage to crops and to keep from pounding on the soil surface, or in surface drain that are crossed by farm equipment without causing soil erosion."

\subsection{Subsurface Drainage}

Subsurface drainage (SSD) is the removal of excess of soil in time to prevent damage to the crops because of a high ground water table. Subsurface field drains can be either open ditcher or pip drains pipe drains are installed underground at depths varying from 1 to $3 \mathrm{~m}$. Excess groundwater excess the perforated field drain and flows by gravity to the open or closed collector drain. 


\subsection{Vertical Drainage}

In this method tube well, are to be drilled to lower the ground water table where adequate permeability of soil between the crop roof zone and aquifer are available. Vertical drainage is useful where pumped water is qualitatively fit for irrigation through direct application or conjunctive use vertical drainage has been extensively done for lowering of the water table and augmentation of canal supply.

A large number of tube wells have also been installed in Punjab, Bihar, Uttar Pradesh and other states to lower water table. These schemes have also served the purpose of conjunctive use of surface and ground waters.

\subsection{Mole Drainage}

Mole drains are unlined circular soil channels, which function like pipe drains. Mole drainage is an effective method of drainage, which is widely used in the clay soils of temperate region such as United Kingdom, northern Europe and in New Zealand. It is generally confined to soils having clay content of about $30-35 \%$. Their diced is their restricted life (5 to 10 years), but, providing benefit cost ratios are favourable, a short life can be acceptable. Mole drains are formed with a mole plough, which comprises a cylindrical foot attached to a narrow leg, followed by a slightly larger diameter cylindrical expander. The foot and expander from the drainage channel and the leg generator the shot with associated soil fissures which extend from the surface down into the channel. The leg fissures are vertical and formed at an angle of approximately 450 to the direction of travel.

Mole drains are commonly installed at depths between 0.4 and $0.7 \mathrm{~m}$, but can be installed up to depth of $1.2 \mathrm{~m}$. The mole drain spacing range between 2 to $5 \mathrm{~m}$. Common lengths of mole drains vary from $20 \mathrm{~m}$ to $100 \mathrm{~m}$ long depending on the grade, which may range from nearly level to 5 percent. Mole drains are installed using a mole plough, pulled by a powerful tractor (drawbar pull $40-60 \mathrm{KN}$ ). The success of a mole drainage system is dependent upon satisfying two requirements achieving the desired water flow path for the particular drainage situation, and installing stable mole channels. Hence following are the objectives,

1. To study the effect of mole drainage system at various spacing on the plant height, No. of branches per plant, No. of pods per plant, Weight of pods per pant and total yield of summer groundnut.

2. Comparison of different crop parameters of summer groundnut at the different spacing of mole drain.

\section{MATERIALS AND METHOD}

\subsection{Field Layout}

An experimental layout of mole drains was prepared with three different spacing $(2,4 \& 6 \mathrm{~m})$ and five supplications with $2 \mathrm{~m}$ buffer strip.

In the area of $44 \mathrm{x} 40 \mathrm{~m}, 3$ laterals of each spacing i.e. $2,4 \& 6$ $\mathrm{m}$ were installed. Putting a space of $1 \times 40 \mathrm{~m}$ at the starting of the plot drains of 2, 4 and $6 \mathrm{~m}$ were separated by the area of $3 \mathrm{x}$ $40,5 \times 40$ and $60 \times 40 \mathrm{~m}$ susceptive, adjust to this plot a control plot of $6 \times 40$ was also separated by a $2 \times 40 \mathrm{~m}$ buffer strip. The details topography plot is shown in fig no.

\subsection{Selection of Site and Soil Condition}

1. Moisture content in soil:-Usually when the clay at mole draining depth has moisture content of $20-30 \%$ conditions are satisfactory. The tests were conducted in the field when the moisture content was $26 \%$.

2. Topography: - The mole channel constructed need to be graded either during mole plough or by selection of inclined field Topography for efficient disposal of drained water. A field with average slope of $1.5 \%$ was selected and moling operation was planned along the slope of the field starting from lower end upper end.

\subsection{Selection of Different Parameters for Mole Drainage System}

\subsubsection{Spacing of Drains}

The spacing of mole drains varies from 2 to $5 \mathrm{~m}$ in the experiments conducted in U.K. and New Zealand. However, it depends on the soil permeability and the necessity of drainage also. If the spacing is less than $2 \mathrm{~m}$, there is a danger of damage of the previously constructed drain where as if the spacing is greater than $5 \mathrm{~m}$ the fissuring effect may not cover the intervening space. So the $2 \mathrm{~m}, 4 \mathrm{~m}$ and $6 \mathrm{~m}$ spacing between the mole channels was selected for the study.

\subsubsection{Depth of Drains}

A rule of thumb is that the expander to mole draining depth is 1:7. As the diameter of expander selected was $85 \mathrm{~mm}$. The depth of drains was planned up to $70 \mathrm{~cm}$.

\subsubsection{Length of Drains}

The length of mole channels depends on the grade of the mole drains formed, soil type, shape, size and topography of the field. Fat slope requires shorter drain. Generally adopted/accepted maximum effective length of moles is show $200 \mathrm{~m}$. However moles up to $400 \mathrm{~m}$ pulled at Cooriemungle in South, West Victoria have performed satisfactorily for a number of years. However, shorter (80-100 m) moles should 
last longer because they empty out quicker and are not likely to be overloaded. So $100 \mathrm{~m}$ length of drain was selected.

\subsubsection{Selection of Tractors}

As the mole plough needs to work at greater depths of 60 to 75 $\mathrm{cm}$ which requires higher power required to pull the plough. The higher horse power tractors radially available in the market and purchased by the farmers are keeping this in a view a $65 \mathrm{HP}$ tractor was selected for the formation of moles.

\subsection{Measurement of Different Parameters Selected in the Study}

\subsubsection{Soil moisture Content}

For measurement of soil moisture content, core samples of soil were taken at different locations of test plot selected randomly were collected in the sample boxes. These boxes were oven dried in a hot air oven at $105^{\circ} \mathrm{C}$ for 24 hours. At the end of 24 hours weight of sample boxes with dry soil and weight of empty boxes were taken. The soil moisture content was calculated by using the formula.

$\begin{array}{lll} & \mathbf{M C}= & \frac{\mathbf{W}_{\mathbf{1}}-\mathbf{W}_{\mathbf{2}}}{\mathbf{W}_{\mathbf{2}}} \times \mathbf{1 0 0} \\ \text { Where, } & & \\ \mathrm{MC} & = & \text { moisture content, percent (dry basis) } \\ \mathrm{W}_{1}= & \text { weight of moist soil sample, } \mathrm{kg} \text { and } \\ \mathrm{W}_{2}= & \text { weight of dry soil sample, } \mathrm{kg} .\end{array}$

\subsubsection{Bulk Density}

It is the mass of oven-dried soil per unit volume. For measurement of bulk density of soil, a cylindrical core sample $(100 \times 120 \mathrm{~mm})$ was taken and soil samples were taking at different locations in a plot. Core sample was kept in air oven for 24 hours and after 24 hours weight of soil sample was taken with electrical balance. Bulk density was calculated by using following formula.

$$
\mathrm{BD}=\frac{M}{\mathrm{~V}}=\frac{4 M}{\pi \mathrm{D}^{2} \mathrm{~L}}
$$

\begin{tabular}{|c|c|c|}
\hline Where, & & \\
\hline & $=$ & bulk density, $\mathrm{kg} / \mathrm{m}^{3}$ \\
\hline $\begin{array}{l}\text { M } \\
\text { sample, }\end{array}$ & $=$ & mass of soil sample contained in the core \\
\hline $\mathrm{V}$ & $=$ & volume of core sample $\mathrm{m}^{3}$ \\
\hline $\mathrm{D}$ & $=$ & diameter of cylindrical core sample, $\mathrm{m}$ \\
\hline $\mathrm{L}$ & $=$ & length of cylindrical core sample, $\mathrm{m}$ \\
\hline
\end{tabular}

\subsection{Measurement of Different Parameters}

This section deals with different measurement techniques used for measuring various parameters in the study.

\subsubsection{Plant Height}

An area of size $5 \mathrm{~m} \times 2 \mathrm{~m}$ was selected and plant selected randomly and plant height was measured with the help of scale from ground level to the top of leaf of plant.

Plant height was measured again with every 20 days interval. Then adding pods of all five plants. That was the number of pods in that replication.

\subsubsection{Number of Branches per Plant}

An area of size $5 \mathrm{~m} \times 2 \mathrm{~m}$ was selected and plant selected randomly and plant branches were counted manually.

\subsubsection{Number of Pods per Plant}

An area of size was selected, randomly and five plants were selected of that area. From the selected plants, the number of ponds of each plant was computed. Then adding pods all pods of all five plants and total number of pods were recorded. The average value of number of pods was taken from five such readings.

\subsubsection{Weight of Pods Yield per Plant}

An area of size was selected, randomly and five plants were selected of that area. From the selected plants, the number of ponds of each plant was computed. Then adding pods all pods of all five plants and total number of pods were recorded. The average value of number of pods was taken from five such readings weight of that pods were taken with the help of electronic balance.

\subsubsection{Total Yield of Dry Pods}

After harvesting the yield of dry pods was weighted with electronic balance and calculated total yield in $\mathrm{qt} / \mathrm{ha}$.

\section{RESULTS AND DISCUSSION}

\subsection{Biometric and Yield Contributing Characteristics of Groundnut Crop}

Biometric and yield contributing characteristics where found very good at mole spacing of $4 \mathrm{~m}$ than $6 \mathrm{~m}, 2 \mathrm{~m}$ and control. This may be due to the spacing of $4 \mathrm{~m}$ have the right amount of water to the plant and remaining water was easily drain off.

At $6 \mathrm{~m}$ mole spacing their was slow rate off of the water because of spacing was too large. At $2 \mathrm{~m}$ mole spacing their is higher rate of drainage of water because of spacing is too small. At control it was found ponding of water because of 
clay content in the soil. From the above table it can be seen that biometric and yield contributing characteristics are better in mole drain plot. As compare to control. The highest yield is obtained from $4 \mathrm{~m}$ spacing of the drain than $6 \mathrm{~m}$ and $2 \mathrm{~m}$ spacing control has lowest yield. The data was collected from 5 replication of each spacing is given below in the following table

Table 1 Biometric and Yield Contributing Characteristics of Groundnut Crop

\begin{tabular}{|c|l|c|c|c|c|}
\hline $\begin{array}{c}\text { Sr. } \\
\text { No. }\end{array}$ & Characteristics & $\mathbf{2 ~ m}$ & $\mathbf{4 ~ m}$ & $\mathbf{6 ~ m}$ & Control \\
\hline 1. & $\begin{array}{l}\text { Height of Plants } \\
(\mathrm{cm})\end{array}$ & 22.69 & $\mathbf{2 5 . 3 2}$ & 24.32 & 22.14 \\
\hline 2. & $\begin{array}{l}\text { No. of Branches } \\
\text { per Plant }\end{array}$ & 2 & $\mathbf{7}$ & 6 & 5 \\
\hline 3. & No. of Pods & 9 & $\mathbf{1 1}$ & 10 & 8 \\
\hline 4. & $\begin{array}{l}\text { Weight of Pods } \\
\text { per Plant (gm) }\end{array}$ & 11 & $\mathbf{1 4}$ & 12 & 10 \\
\hline 5. & $\begin{array}{l}\text { Total Yield of } \\
\text { Dry Pods } \\
(\mathrm{qt} / \mathrm{ha})\end{array}$ & 19.065 & $\mathbf{2 6 . 0 9 6}$ & 20.884 & 18.02 \\
\hline
\end{tabular}

From the table 1 shown that the Average yield is $26.096 \mathrm{qt} / \mathrm{ha}$ in $4 \mathrm{~m}$ spacing while $20.884 \mathrm{qt} / \mathrm{ha}$ and $19.06 \mathrm{qt} / \mathrm{ha}$. In $6 \mathrm{~m}$ and $2 \mathrm{~m}$ spacing respectively. Control has lowest yield of 18.02 $\mathrm{qt} / \mathrm{ha}$. It was found that their no significant difference in yield of $2 \mathrm{~m}, 4 \mathrm{~m}$ and $6 \mathrm{~m}$ spacing higher the spacing, lower will be cost of installation their fore the spacing of $4 \mathrm{~m}$ can be $6 \mathrm{~m}$ adopted in the reason of Digraj, Dist. Sangli.

\section{SUMMARY AND CONCLUSIONS}

The research work carried out earlier has shown the effective installation of mole drains at various depths. The effect of mole drainage system on the crop parameters are studied on soybean. The mole plough manufactured last year studied and evaluated for its performance at various depths. The effect of the mole plough developed needs to be studied from the crop point of view so the present study undertaken to study the effect of mole drains spacing on summer groundnut yield.

To study the effect of mole drainage system at various spacing on the plant height, No. of branches per plant, No. of pods per plant, Weight of pods per pant and total yield of summer groundnut Comparison of different crop parameters of summer groundnut at the different spacing of mole drain $\mathrm{A}$ tractor $65 \mathrm{HP}$ was selected to make drains of $2 \mathrm{~m}, 4 \mathrm{~m}$ and $6 \mathrm{~m}$. The effect of mole drain spacing at $2 \mathrm{~m}, 4 \mathrm{~m}$ and $6 \mathrm{~m}$ plot without drain i.e. control were studied by standard procedure and following conclusions were made.

The plant height, No. branches per plant, No. of pods per plant, weight of pods per plant was highest in $4 \mathrm{~m}$ drain spacing followed by $6 \mathrm{~m}, 2 \mathrm{~m}$ and control plot. The total yield of groundnut was highest in $4 \mathrm{~m}$ mole spacing followed by $6 \mathrm{~m}$, $2 \mathrm{~m}$ and control and the total yield in $4 \mathrm{~m}$ drain was $69.20 \%$ more than the control. This might be due to the reason that, the area with $2 \mathrm{~m}$ spacing of drains was over drained due to close spacing of drains where as the an area with $6 \mathrm{~m}$ drain spacing was under drained due to wide spaced mole drains.

\section{REFERENCES}

[1] Anoymous, 1999. Progress Report of ICAR coordinated research project of agricultural drainage under actual farming of watershed basis. Department of soil and water engineering college of Agricultural Engineering, PAU, Ludhiana.

[2] ASAE, Surface drainage committee. 1979. Design and construction of surface drainage system on farms in humid areas. Engineering Practice EP 302.2. American society of agricultural engineers, Michigan, 9p.

[3] Eodwin, R.J. G. Spoor, P.B. Leeds, Harrison, 1981. An experimental investigation in to the force mechanics and resulting soil distribution of mole plough. J. of Agril. Engg. Res. 26 : 477-479.

[4] Mishra, A.K., Sarkarkar, T.K. and A.K. Bhattacharya. 2000. Simulation studies of mole drain characteristics. J. of Agril. Engg. 37 (1) : 39-54.

[5] Ramana Rao, K.V. 2006. Principals of mole drainage and its economical feasibility in vertisoil, CIAE Bhopal. Pp. 144-148.

[6] Ramana Rao, K.V. 2006.Indian experiences of mole drainage system, CIAE Bhopal. Pp. 149-153. 